\title{
The Possible Protective and Therapeutic Effects of Mesenchymal Stem Cells Compared to Vitamin C in Gentamicin Induced Acute Kidney Injury in Adult Rats : A Histological Study
}

\author{
Walaa Baher, Asmaa A Abo Zeid and Hadwa Ali Abd Al-Khalek
}

Department of Histology and Cell Biology, Faculty of Medicine, Ain Shams University, Egypt

\begin{abstract}
Purpose: This study was designed to evaluate the possible nephroprotective and therapeutic role of bone marrow mesenchymal stem cells (BMSCs) in comparison to vitamin C in a rat model of gentamicin (GM) induced nephrotoxicity.

Materials and Methods: Forty adult male Wistar rats (150-200 gm) were used in this study. Five rats were utilized to obtain BMSCs and thirty-five rats were divided into: Group I: control, Group II (GM): received $100 \mathrm{mg} / \mathrm{kg} \mathrm{GM}$ intramuscularly for 8 days, subdivided into: subgroup IIa (GM toxicity): sacrificed after the last dose of GM; and subgroup IIb (GM recovery): sacrificed 8 days after the last injection; Group III (Protection): subdivided into: subgroup IIIa (BMSCs protection): received a single intravenous (IV) injection of BMSCs with the first dose of GM and subgroup IIIb (Vitamin C protection): received $200 \mathrm{mg} / \mathrm{kg}$ vitamin C intraperitoneal (IP) for 8 days simultaneously with the daily GM doses; and Group IV (Treatment): subdivided into: subgroup IVa (BMSCs treatment): received single IV injection of BMSCs after the last dose of GM and subgroup IVb (Vitamin C treatment): received $200 \mathrm{mg} / \mathrm{kg}$ vitamin C IP for 8 days after the last dose of GM. Serum creatinine and urea were measured, and kidneys were processed for histological, immunohistochemical and morphometric studies.

Results: GM resulted in vacuolation, desquamation of tubular epithelium, interstitial inflammation, congestion and increased number of PCNA positive cells. Serum creatinine and urea were significantly increased. Vitamin C administration, either as a treatment or protection, significantly ameliorated these changes. Conversely, BMSCs could not prevent the GM toxicity but exerted a therapeutic role.

Conclusion: BMSCs had no role in protection against GM nephrotoxicity, whereas, their administration after kidney injury assisted kidney regeneration. However, vitamin $\mathrm{C}$ exhibited a dual significant role in prevention and improvement in kidney structure and biochemical results.
\end{abstract}

Received: 08 April 2019, Accepted: 12 April 2019

Key Words: BMSCs, gentamicin, nephrotoxicity, PCNA, vitamin C.

Corresponding Author: Walaa Baher, MD, Department of Histology and Cell biology, Faculty of Medicine, Ain Shams University, Abassyia, Cairo 11358, Egypt, Tel.: +20 1002050563, Fax: +20 222909854, E-mail: walaa_baher@med.asu.edu.eg

ISSN: 1110-0559, Vol. 42, No. 4

\section{INTRODUCTION}

Gentamicin (GM) is a member of aminoglycoside antibiotics that is widely used for the treatment of gramnegative infections ${ }^{[1]}$. Despite the potential nephrotoxicity and ototoxicity associated with its administration, gentamicin remained valuable and sometimes crucial for the treatment and prophylaxis of various infections due to its concentration-dependent bactericidal activity, postantibiotic effect, relatively predictable pharmacokinetics, synergism with other antibiotics, low cost and low antimicrobial resistance ${ }^{[1,2]}$.

Vast experimental evidenced studies suggested multifaceted pathological mechanisms involved in GM induced nephrotoxicity ${ }^{[3,4]}$. Although most of the advances in the area of GM nephrotoxicity were focused on the molecular biology of the mechanisms of the nephrotoxicity and its pathophysiology, only few studies were concerned with novel agents that could be utilized to ameliorate or prevent the toxicity.
The oxidative stress underlying the mechanism of GM induced nephrotoxicity suggested the role for antioxidants as protective agents against damages affecting glomerular and tubular functions. Vitamin $\mathrm{C}$, a potent natural antioxidant was reported by some studies as a powerful agent in reducing oxidative stress, scavenging free radicals and reestablishing antioxidative systems, thus protecting the kidney against GM associated oxidative stress and preserving normal renal functions ${ }^{[5-7]}$.

Bone marrow derived mesenchymal stem cells (BMSCs) were defined as self-renewable, multipotent progenitor cells that can differentiate into several distinct mesenchymal lineages ${ }^{[8,9]}$. Transplantation of BMSCs from rodents was applied by some studies as a strategy for renal repair in experimental models of acute kidney injury ${ }^{[10-12]}$.

The mechanism for the effects of BMSCs remained controversial, some studies reported that the injected BMSCs infiltrate the kidney and directly populate the injured renal tubule ${ }^{[9]}$. Other studies found no evidence for 
direct BMSCs incorporation into the tubules during the repair processes ${ }^{[13]}$.

Although, many studies investigated the role of BMSCs $^{[1,8,9]}$ and antioxidants ${ }^{[5-7]}$ on the kidney in GM toxicity, to date, no reports have combined or compared them in a single study.

Therefore, the objective of our study was to compare the possible effects of BMSCs and vitamin $\mathrm{C}$ on prevention and/or treatment of GM induced nephrotoxicity in adult male Wistar rats.

\section{MATERIAL AND METHODS}

\section{Experimental animals}

Forty adults male Wistar rats, 8-10 weeks old, weighing 150-200 gm were purchased from and raised in Medical Research Center, Faculty of Medicine, Ain Shams University, Cairo, Egypt. They were maintained under a $12 \mathrm{~h}$ light $/ 12 \mathrm{~h}$ dark cycle, with food and water ad libitum. All procedures for animal care and experiments were done in accordance with Ain Shams University research ethics committee guidelines.

\section{Isolation of rat BMSCs}

Five rats were sacrificed to obtain MSCs from their long bones. The Bone marrow was flushed out from the bones, cultured in complete medium, seeded into tissue culture flasks $\left(25 \mathrm{~cm}^{2}\right)$ and incubated at $37{ }^{\circ} \mathrm{C}$ in a humidified incubator containing 5\% $\mathrm{Co}^{2}$. When the cells showed 70$80 \%$ confluence, subculture was performed. The cells in 3 rd passage were utilized in this experiment ${ }^{[14]}$

\section{Flow cytometry analysis of BMSCs}

The phenotype of the third passaged BMSCs was analyzed by flow cytometry. The cells were harvested with trypsin/EDTA and suspended at a concentration of $1 \times 10^{5}$ cells $/ 100 \mu \mathrm{l}$ of PBS. The cells were stained and incubated with fluorescein isothiocyanate (FITC)-conjugated antibodies against $\mathrm{CD} 44$ and $\mathrm{CD} 45$, monoclonal antibodies (Thermo Fisher Scientific, USA). The cells were washed in PBS, fixed with 1\% paraformaldehyde for 15min. FAC Scan Flow cytometer (BD Biosciences) was used to analyze the specific surface antigen profile of the cells ${ }^{[15]}$.

\section{Study design}

In this study thirty-five rats were divided randomly into 4 groups:

- Group I (Control): $(\mathrm{n}=5)$ served as negative control group, in which normal kidney specimens were obtained.

- Group II (gentamicin): $(\mathrm{n}=10)$, animals in this group, received a daily intramuscular (IM) dose of $100 \mathrm{mg} / \mathrm{kg}$ GM (gentamicin sulfate injection, Schering-plough corporation/ USA) in hind limb for 8 days $^{[16]}$, then were equally divided into; Subgroup IIa (GM toxicity): $(\mathrm{n}=5)$, in which animals were sacrificed after the last dose of GM (i.e. after 8 days from the beginning of experiment) and subgroup IIb (GM recovery): $(\mathrm{n}=5)$, in which animals were allowed to survive for further 8 days after the last injection, then sacrificed (i.e. after 16 days from the beginning of experiment).

- Group III (Protection): $(\mathrm{n}=10)$, animals in this group were equally divided into; Subgroup IIIa (BMSCs protection): $(\mathrm{n}=5)$, in this subgroup, animals received a single intravenous (IV) injection of $1 \times 10^{6}$ BMSCs suspended in $0.5 \mathrm{ml}$ PBS simultaneously with the first dose of GM and Subgroup IIIb (Vitamin C protection): $(n=5)$, in which animals received a daily intraperitoneal (IP) dose of $200 \mathrm{mg} / \mathrm{kg} \mathrm{L}$ ascorbic acid (vitamin C) (Sigma Aldrich, St. Louis MO, USA) for 8 days simultaneously with the daily GM doses.7. All rats in this group were sacrificed after further 8 days, i.e. 16 days from the beginning of experiment.

- Group IV (Treatment): $(\mathrm{n}=10)$, animals in this group were equally divided into Subgroup IVa (BMCs treatment): $(n=5)$, in which animals received a single IV injection of $1 \times 10^{6}$ BMSCs suspended in $0.5 \mathrm{ml}$ PBS simultaneously with the last dose of GM and Subgroup IVb (Vitamin C treatment): $(n=5)$ in which animals received daily IP dose of $200 \mathrm{mg} / \mathrm{kg}$ vitamin C for 8 days starting from the last dose of GM. All rats in this group were sacrificed after further 8 days, i.e. 16 days from the beginning of experiment.

\section{Biochemical analysis}

At the end of the experiment, blood samples from all rats were collected via cardiac puncture method. The serum was rapidly separated and processed for determination of serum creatinine and serum urea.

\section{Histological studies and grading}

The kidneys of all rats were sectioned longitudinally into two halves and fixed immediately in $10 \%$ neutral formalin solution, processed and embedded in paraffin blocks to obtain $5 \mu \mathrm{m}$ thick sections. The sections were stained with hematoxylin and eosin (H\&E) and modified Masson`s trichrome ${ }^{[17]}$.

Semiquantitative analysis and histological grading of H\&E stained kidney sections was performed. Three different sections from each rat in each group (total 15 sections / group) were examined for proper histological grading. The severity of injury was inspected in the renal cortex and was graded as followed according to Houghton et al. ${ }^{[18]}$ :

$0=$ normal; $1=$ desquamation of tubular epithelial cells in small foci (less than $1 \%$ of total tubule population involved); 2 = tubular epithelial necrosis and desquamation easily seen but involving less than half of cortical tubules; $3=$ more than half of cortical tubules show desquamation 
and necrosis but uninvolved tubules easily found; $4=$ complete or almost complete proximal tubular necrosis.

\section{Immunohistochemical studies}

Indirect Immunohistochemical staining using AvidinBiotin immune-peroxidase technique for detection of proliferating cell nuclear antigen (PCNA) (mouse anti-rat monoclonal antibody PC10, Dako, Denmark) and cluster of differentiation 44 (CD44) (mouse anti-rat monoclonal antibody OX49, Pharmingen, San Diego, CA, USA), was performed according to manufacturer's recommendations. PCNA appeared as brown nuclear staining, while that of CD44 appeared as brown cytoplasmic staining.

To confirm the specificity of the immunohistochemical staining, the primary antibody was omitted from staining kidney sections of GM toxicity subgroup (for PCNA) and stem cell treated subgroup (for CD 44), which served as negative controls.

Moreover, positive control for the primary antibody against PCNA was tested on a rat skin section and against CD44 was tested on a rat spleen section.

\section{Morphometric measurements}

The mean area percentage of collagen fibers stained with Masson's trichrome stain and the mean number of positive immune-reactivity for PCNA in the tubular epithelium/ high power field were measured in five non overlapping fields from five different sections of different rats in each group at objective lens X 20 and X 40 respectively. Measurements were performed at image analysis unit at Histology and Cell Biology department, Faculty of Medicine, Ain Shams University using Leica Q win V.3 program installed on a computer connected to a Leica DM2500 microscope (Wetzlar, Germany).

\section{Statistical analysis}

The measured parameters (biochemical \& morphometric measurements) in the different subgroups were expressed as mean \pm standard deviation (SD) and were compared with each other using the statistical package for the social sciences (SPSS) computer program (version 19.0. IBM Corporation, New York-USA), analysis for variance (ANOVA)-one-way analysis and post-Hoc least significant difference (LSD). Differences were considered significant when the $p$ value (probability of chance) was $\leq 0.05$.

\section{RESULTS}

\section{Morphology, immunophenotype of BMSCs}

The morphological features of the BMSCs were shown in (Figure 1). The $3^{\text {rd }}$ passaged BMSCs showed the typical fibroblast like homogenous morphology in vitro. The expression of cell surface markers on BMSCs was evaluated by flow cytometry. As illustrated in (Histogram 1), 99.9\% of BMSCs were positive for the mesenchymal marker CD44 (hyaluronate receptor), whereas less than $12.4 \%$ expressed the hematopoietic marker CD45 (common leukocyte antigen).

\section{Renal Histological Studies}

\section{$H \& E$ stain results}

Examination of H\&E stained sections of the kidney cortex of the control group showed entirely normal histological feature. The renal cortex was formed of Malpighian corpuscles which appeared as spherical structures surrounded by Bowman's membrane enclosing a narrow clear Bowman's space. The glomerulus appeared as a large cellular mass. Proximal convoluted tubules were having a narrow star shaped lumen, lined by single layer of acidophilic cuboidal cells having apical brush border. The distal convoluted tubules were having a wider lumen with sharper luminal surface and lined by more cells at cross sections. Also, the cells lining the distal tubules were crowded at one side at the vascular pole of the Malpighian corpuscles forming the macula densa of the juxtaglomerular apparatus (Figure 2).

Renal cortex of GM toxicity subgroup (subgroup IIa) showed marked disruption of the renal cortex histology. Proximal and distal tubules were hardly distinguished. The tubular epithelium showed vacuolation and desquamation into the lumina of the tubules. The desquamated cells partially obliterated the lumina of some tubules. Moreover, homogenous eosinophilic materials were detected in the tubular lumina in other tubules. The epithelium lining some tubules showed dark shrunken pyknotic nuclei. Foci of inflammatory cells and congested dilated peritubular capillaries were demonstrated in between the cortical tubules. Moreover, renal corpuscles showed shrinkage of their glomerular capillary loops (Figures 3 and 4).

In the GM recovery subgroup (subgroup IIb), some of the histopathological changes induced by GM toxicity were still detected in some sections. These changes were in the form of atrophied glomeruli with shrunken glomerular capillary loops and wide Bowman's space together with inflammatory cells infiltration within the interstitial space. The renal tubules showed either obliterated lumina or wide lumina. The nuclei of the lining epithelia were pyknotic in some tubules, while in other tubules appeared vesicular. Moreover, some tubular epithelial cells showed cytoplasmic blebbing at the apical region. Also, wide separation between epithelial cells lining some renal tubules was seen (Figures 5 and 6).

Co-administration of BMSCs with GM subgroup IIIa (BMSCs protection) could not prevent the occurrence of GM induced injury. Distorted cortical structure was detected in the form of loss of the tubular epithelial lining, sloughing of epithelial cells into the lumina of the cortical tubules, vacuolation of epithelial cells and loss of their brush border. Also dilated congested peritubular capillaries were seen (Figure 7).

On the contrary, co-administration of vitamin $\mathrm{C}$ with $\mathrm{GM}$ in vitamin $\mathrm{C}$ protection (subgroup IIIb), resulted in a histological profile of the renal cortex comparable to the control group. Most of the tubules were crowded with 
proliferating epithelial cells having large vesicular nuclei. Other tubules showed star shape lumina and were lined with deep acidophilic cuboidal epithelium. However, few tubules demonstrated wide lumina lined with slightly separated epithelial cells, while others showed few desquamated cells in their lumina (Figure 8).

Examination of sections of the renal cortex of BMSCs treatment group (subgroup IVa) showed dilated regenerating cortical tubules. Some of these dilated tubules were lined with low cuboidal cells with vesicular nuclei, while others were lined with flattened cells with darkly stained flat nuclei. Few cortical tubules showed shedding of their epithelial lining and obliteration of their lumina (Figure 9).

On the other hand, sections of the renal cortex of Vitamin C treatment (subgroup IVb) showed a histological profile comparable to the control. Proximal and distal convoluted tubules could be distinguished. Proximal tubules were having narrow star shaped lumina, while the lumina of distal tubules were wider. The tubules were lined with deep acidophilic cuboidal cells having vesicular nuclei. Renal corpuscles showed intact structure (Figure 10).

\section{Semiquantitative analysis and histological grading (Table 1)}

Semiquantitative analysis of the histological grading reveled that vitamin $\mathrm{C}$ subgroups whether protection (subgroup IIIb) or treatment (subgroup IVb) were the least affected subgroups, followed by BMSCs treatment subgroup (subgroup IVa). In contrast, GM toxicity subgroup (subgroup IIa) was the most affected group, followed by GM recovery (subgroup IIb) and BMSCs protection (subgroup IIIa) respectively.

In the control group, 13 examined sections were showing no abnormalities in structure. However, 2 sections showed small foci of desquamated tubular epithelial cells that represent less than $1 \%$ of the total tubules in the renal cortex.

In the GM group (group II), the GM toxicity subgroup (subgroup IIa), 14 examined sections were showing complete necrosis of the cortical tubules, whereas, only a single section showed a small area of uninvolved tubules. In the GM recovery subgroup (subgroup IIb), two thirds of the examined sections showed complete necrosis of the cortical tubules. However, in the majority of the remaining one third of the examined sections, small areas of nonnecrotic tubules were detected. Only in a single examined section, less than half of the cortical tubules were necrotic.

In the protection group (group III); the BMSCs protection subgroup (subgroup IIIa), showed almost similar results as subgroup IIb (GM recovery). On the other hand, in subgroup IIIb (vitamin C protection), two thirds of the examined sections showed unremarkable histological changes. The remaining one third of the examined sections showed small areas of desquamated tubular cells in less than $1 \%$ of the total tubules in the renal cortex.
In the treatment group (group IV); BMSCs treatment subgroup (subgroup IVa), 12 examined sections revealed small foci of desquamated tubular cells in less than $1 \%$ of the total cortical tubules. One examined section showed unremarkable histological changes. However, in two examined sections, less than half of the cortical tubules showed desquamation and necrosis of the tubular epithelium. Alternatively, in vitamin $\mathrm{C}$ treatment subgroup (subgroup IVb), 12 the examined sections showed no remarkable histological changes. Yet, in three examined sections, small foci of desquamated cortical epithelium were detected in less than $1 \%$ of the total tubules in the cortex.

\section{Masson's trichrome stain results}

Masson's trichrome stained sections in all subgroups (Figure 11), revealed collagen fibers deposition in the cortical interstitium around the renal corpuscles and the renal tubules. This deposition was very minimal in the control group and appeared as a thin rim surrounding the cortical structures (Figure 11A). However, in subgroup IIb (GM recovery) and subgroup IVb (vitamin $\mathrm{C}$ treatment) collagen deposition in the interstitial spaces was evident compared to other subgroups (Figures $11 \mathrm{C}$ and $11 \mathrm{G}$ ). While, in subgroup IIIb (vitamin C protection), collagen deposition was minimally detected in comparison to other subgroups (Figure 11E).

Almost no apparent difference in collagen deposition was detected microscopically between subgroups IIa (GM toxicity), IIIa (BMSCs protection) and IVa (BMSCs treatment) (Figures 11B, 11D and 11F).

These findings were further morphologically measured and statistically analyzed to confirm the microscopic results.

\section{Immunohistochemical stain results}

Epithelial tubular cells undergoing active proliferation were identified by immunohistochemical staining against PCNA (Figure 12). Gentamicin administration (subgroup IIa) for 8 days caused a dramatic increase in cell proliferation in the renal cortex, as compared to other groups (figure 12B). In subgroups IIb (GM recovery), IIIa (BMSCs protection), IVa (BMSCs treatment) and $\mathrm{IVb}$ (vitamin $\mathrm{C}$ treatment) the number of PCNA-positive cells were apparently declined as compared to GM toxicity subgroup (Figures12C, 12D, 12F and 12G respectively).

Remarkably, in subgroups IIIb (vitamin C protection) and IVb (vitamin C treatment), most of the detected PCNA were seen in the interstitium around the cortical tubules rather than in the tubular epithelium (Figure 12E and 12G).

Homing of BMSCs into the kidney tissue was identified by positive cytoplasmic reaction to CD44 immunohistochemistry. Homing of the injected BMSCs was detected only in the renal cortical sections of rats of group IVa (BMSCs treatment) (Figure 13A) but not in subgroup IIIa (BMSCs protection) (Figure 13B). 


\section{Statistical analysis results}

\section{Number of PCNA- positive tubular cell/HPF (Table 2)}

The counted PCNA positive tubular cells were maximum (83.2 \pm 2.9$)$ in GM toxicity subgroup (subgroup IIa) and showed significant increase $(P<0.05)$ in comparison to other subgroups. Additionally, in BMSCs treatment subgroup (subgroup IVa), the counted cells $(40.5 \pm 2.08)$ showed significant statistical difference $(P<0.05)$ compared to other subgroups.

Moreover, no statistical difference $(P>0.05)$ was estimated between the PCNA positive cells counted in vitamin $\mathrm{C}$ protection subgroup $(12.7 \pm 1.7)$ and vitamin $\mathrm{C}$ treatment subgroup $(10.1 \pm 0.9)$. However, they showed significant statistical decrease $(P<0.05)$ in comparison to other subgroups.

\section{Area percentage of collagen fibers in renal cortex (Table 2)}

The maximum area percentage of collagen was measured in subgroup IIb (GM recovery subgroup) (12.1 \pm 0.23$)$. This value was significantly increased $(P<0.05)$ in comparison to the control group and other subgroups.

On the other hand, apart from the control group, the minimum area percentage of collagen was measured in vitamin $C$ protection subgroup (10.17 \pm 0.35$)$. Moreover, no significant difference $(P>0.05)$ was measured between GM toxicity $(11.81 \pm 0.31)$, GM recovery $(12.1 \pm 0.23)$, BMSCs protection (11.71 \pm 0.35$)$, BMSCs treatment (11.88 $\pm 0.41)$ and vitamin $C$ treatment $(12.02 \pm 0.30)$ subgroups.

\section{Serum creatinine (Table 3)}

The highest serum creatinine level was measured in GM toxicity subgroup $(1.98 \pm 0.06)$. This value was significantly increased $(P<0.05)$ in comparison to all groups.

On the other hand, the lowest serum creatinine level was measured in vitamin $\mathrm{C}$ treatment subgroup (subgroup IVb) $(0.55 \pm 0.05)$. This value showed a non-significant change $(P>0.05)$ in comparison to the control group $(0.53 \pm 0.02)$ and vitamin $\mathrm{C}$ protection subgroup $(0.59 \pm 0.04)$. However, it showed significant decrease $(P<0.05)$ in comparison to other subgroups.

Additionally, serum creatinine in BMSCs treatment subgroup (subgroup IVa) $(0.71 \pm 0.09)$ showed statistically significant differences $(P<0.05)$ with all groups. These differences showed significant decrease when compared to GM toxicity (1.98 \pm 0.06$)$, GM recovery $(1.59 \pm 0.04)$, and BMSCs protection (1.52 \pm 0.08$)$ subgroups.

\section{Blood Urea Nitrogen (BUN) (Table 3)}

The measured level of BUN in vitamin $\mathrm{C}$ protection
(19.6 \pm 0.88$)$, BMSCs treatment $(19.9 \pm 1.2)$ and vitamin $\mathrm{C}$ treatment $(19.02 \pm 0.89)$ subgroups showed a nonsignificant change $(P>0.05)$ with the control group $(18.9 \pm 0.86)$.

The highest level of BUN was measured in GM toxicity subgroup $(25.3 \pm 0.92)$. This value was statistically increased in comparison to all groups.

On the other hand, no statistical difference $(P>0.05)$ was estimated between GM recovery $(22.1 \pm 1.08)$ and BMSCs protection $(21.9 \pm 1.16)$ subgroups.



Fig. 1: Photomicrograph showing BMSCs in culture at third passage almost all cultured cells appear of homogeneous fibroblast-like morphology. (Phase contrast, X200)

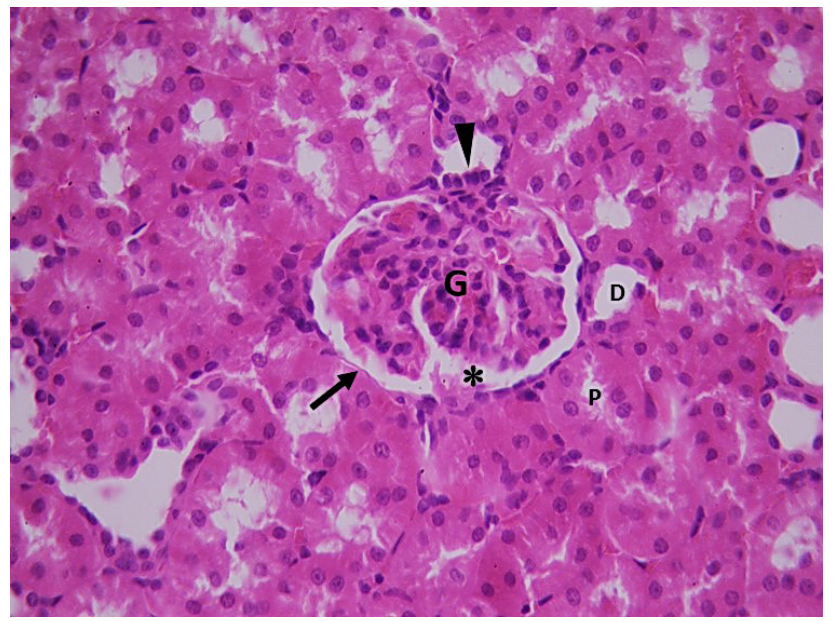

Fig. 2: Renal cortex of control (group I) showing a spherical renal corpuscle lined by Bowman's capsule $(\uparrow)$, the glomerulus $(\mathrm{G})$ appears as a large cellular mass surrounded by a urinary space. Proximal convoluted tubules (P) are having narrow star shaped lumen and are lined by acidophilic cuboidal cells with apical brush border. The distal convoluted tubule (D) are seen having wider lumen and are lined by more cells at cross section. Notice, the crowded nuclei in the wall of the distal tubules at the vascular pole of a renal corpuscle forming macula densa $(\boldsymbol{\Delta})$. (H\&EX400) 


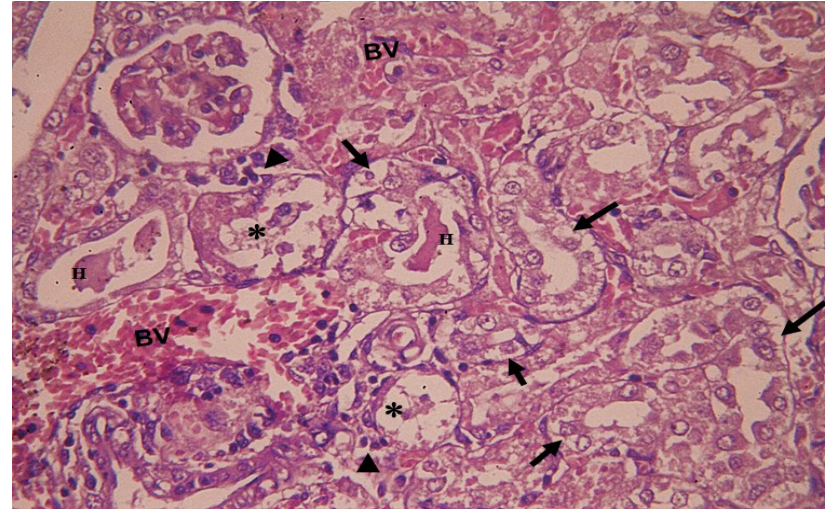

Fig. 3: Renal cortex of GM toxicity (subgroup IIa) showing: distorted microscopic structure of the renal cortex and features of tubules degeneration. The lining epithelium of some tubules is sloughed into their lumina $(*)$. Other tubules show vacuolation of the lining epithelium $(\uparrow)$ and presence of homogenous eosinophilic material in their lumina $(\mathrm{H})$. In between the tubules there are foci of inflammatory cells $(\boldsymbol{\Delta})$ and congested dilated peritubular capillaries (BV). (H\&EX400)

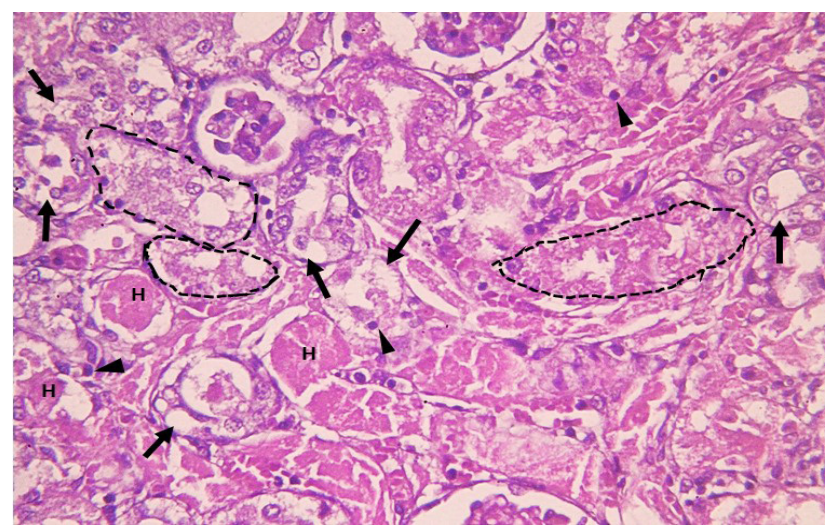

Fig. 4: Another field of a renal cortex of a rat of GM toxicity (subgroup IIa) showing: severely distorted cortical structure. Some tubules have no epithelial lining and their lumina are filled with refractile acidophilic hyaline material $(\mathrm{H})$. Other tubules contain cellular debris partially obliterating their lumina (tubules are demarcated by black dash line). The lining epithelium of some tubules shows vacuolations $(\uparrow)$, and pyknotic nuclei $(\boldsymbol{\Delta})$. (H\&EX400)

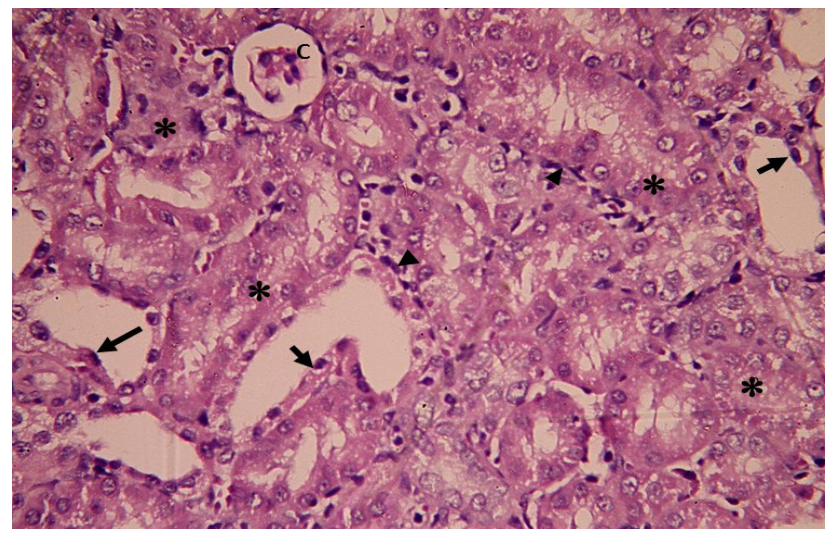

Fig. 5: Renal cortex of a rat of GM recovery (subgroup IIb) showing a small renal corpuscle with shrunken glomerular capillary loops (C) surrounded by wide Bowman's space. Most of the surrounding tubules have obliterated lumina $(*)$. Some tubules have wide lumina and are lined with low cuboidal epithelium having pyknotic nuclei $(\uparrow)$. The interstitial space contains inflammatory cells $(\boldsymbol{\Delta})$. (H\&EX400)

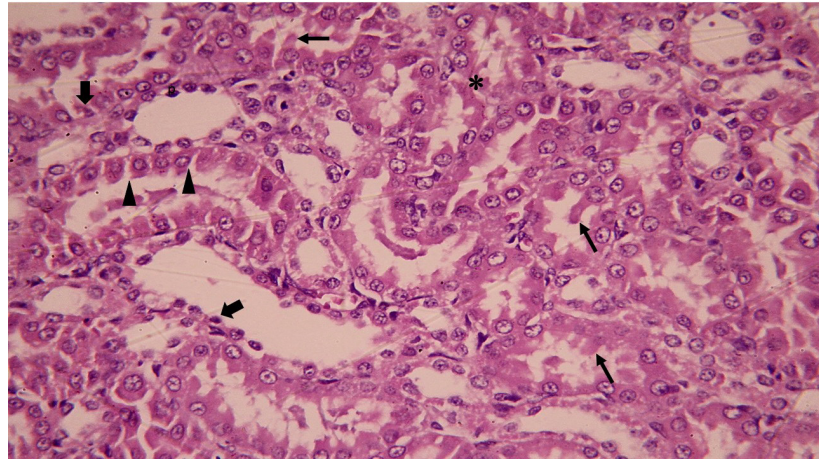

Fig. 6: Another field of renal cortex of a rat of GM recovery (subgroup IIb) showing cortical tubules having wide lumina and are lined with epithelium having vesicular nuclei. However, the lining epithelium of some tubules shows wide separation between cells $(\boldsymbol{\Delta})$. In other tubules, the apical cytoplasm of some epithelial cells shows blebbing $(\uparrow)$ and the nuclei of some cells are pyknotic (thick arrow). Notice that the lumina of some tubules are partially obliterated (*). (H\&EX400)

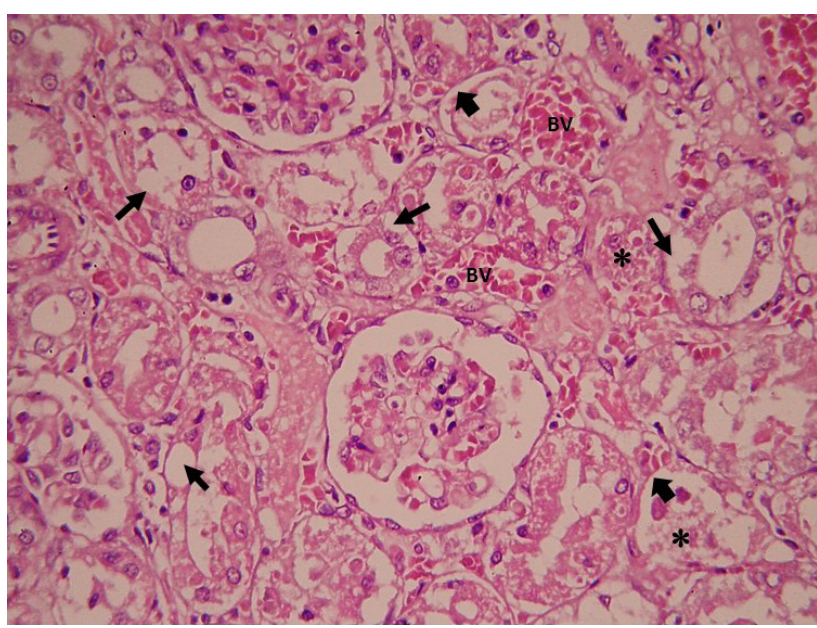

Fig. 7: Renal cortex of a rat of BMSCs protection (subgroup IIIa) showing distorted cortical structure. Some tubules show loss of their epithelial lining (thick arrow). Other tubules show sloughing of their epithelial cells into their lumina (*), and vacuolation of epithelial cells $(\uparrow)$. In between the tubules dilated congested peritubular capillaries (BV) are seen. (H\&EX400)

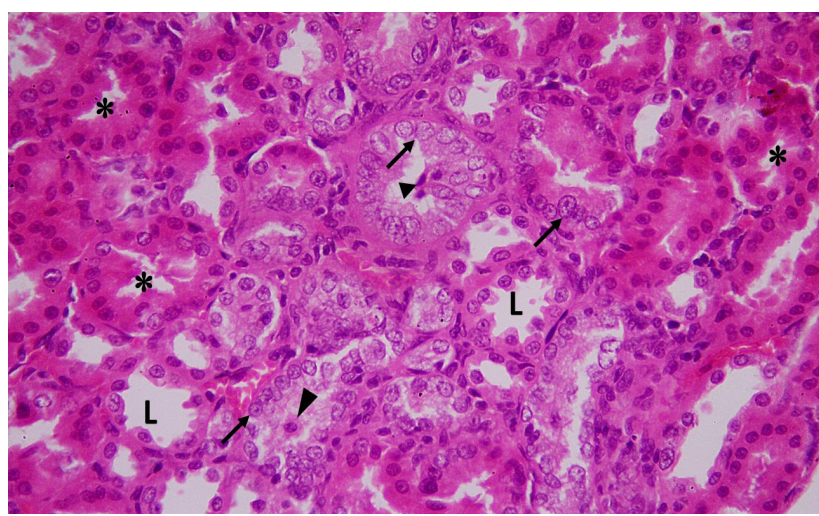

Fig. 8: Renal cortex of rat of Vitamin C protection (subgroup IIIb) showing that most of the tubules are crowded with proliferating epithelial cells having large vesicular nuclei $(\uparrow)$, the rest of the tubules are lined with deep acidophilic cuboidal epithelium and are having star shape lumina (*)comparable to the control group. Few tubules are demonstrating wide lumina lined by slightly separated epithelial cells (L). Notice few desquamated cells in the lumina of few tubules $(\boldsymbol{\Delta})$. (H\&EX400) 


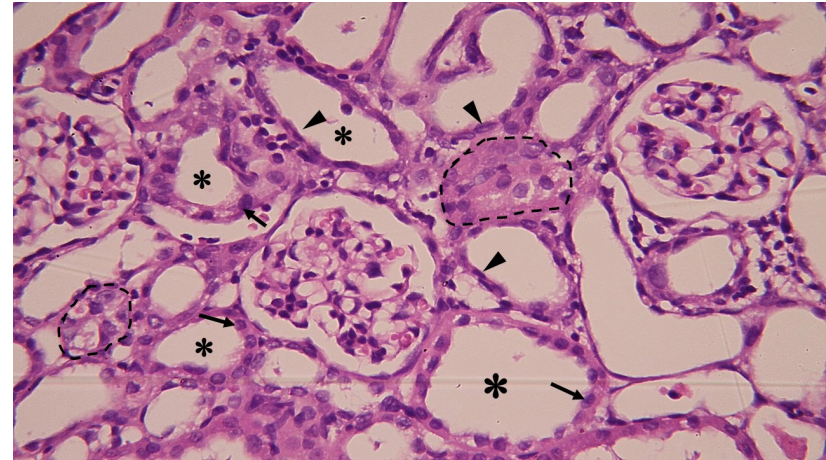

Fig. 9: Renal cortex of a rat of BMSCs treatment (subgroup IVa) showing dilated regenerating cortical tubules $(*)$. The tubules are lined with low cuboidal cells having vesicular nuclei $(\uparrow)$. Other cells lining renal tubules appear flattened with darkly stained flat nuclei $(\boldsymbol{\Delta})$. Only few tubules are still showing sloughing of their epithelial lining into their lumina (dashed line). (H\&EX400)

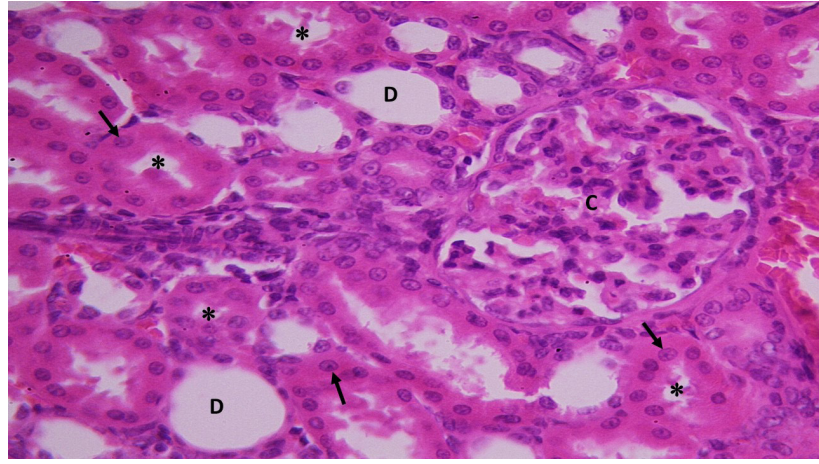

Fig. 10: Renal cortex of a rat of vitamin $C$ treatment (subgroup $I V b$ ) showing intact renal corpuscle $(\mathrm{C})$, surrounded by proximal and dista tubules comparable to the control. Proximal tubules are having star shaped lumina $(*)$ and lined with cuboidal epithelium having deep acidophilic cytoplasm and vesicular nuclei $(\uparrow)$. While, distal tubules are having wider lumina (D) and are lined with acidophilic cuboidal cells. (H\&EX400)

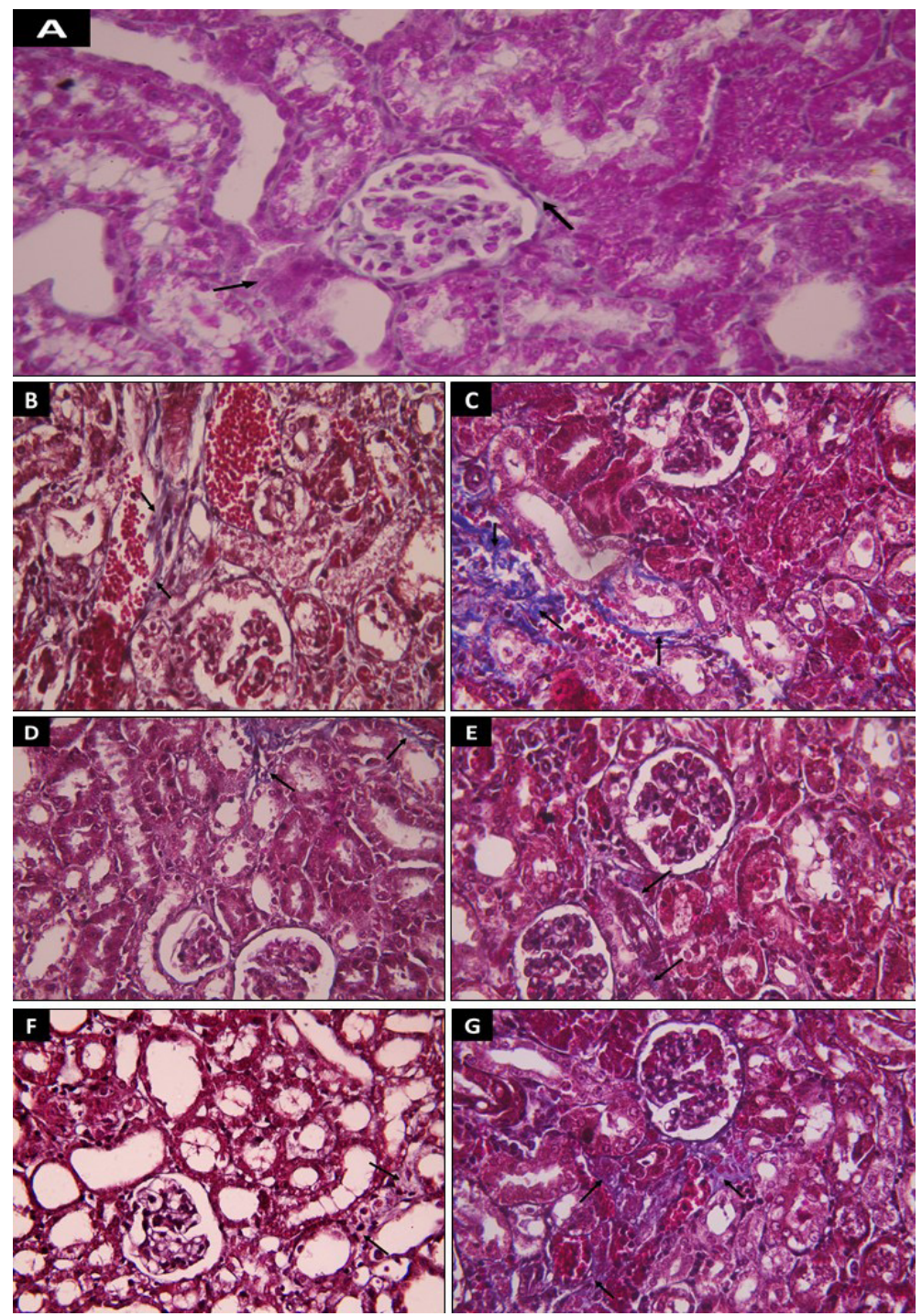

Fig. 11: A photomicrograph showing collagen deposition in between cortical structures in different subgroups ( $\uparrow$ ). (A): Control group; (B); GM toxicity (subgroup IIa); (C): GM recovery (subgroup IIb); (D): BMSCs protection (subgroup IIIa); (E): vitamin C protection (subgroup IIIb); (E): BMSCs treatment (subgroup IVa) and (F): vitamin C treatment. (Masson's trichrome X400) 

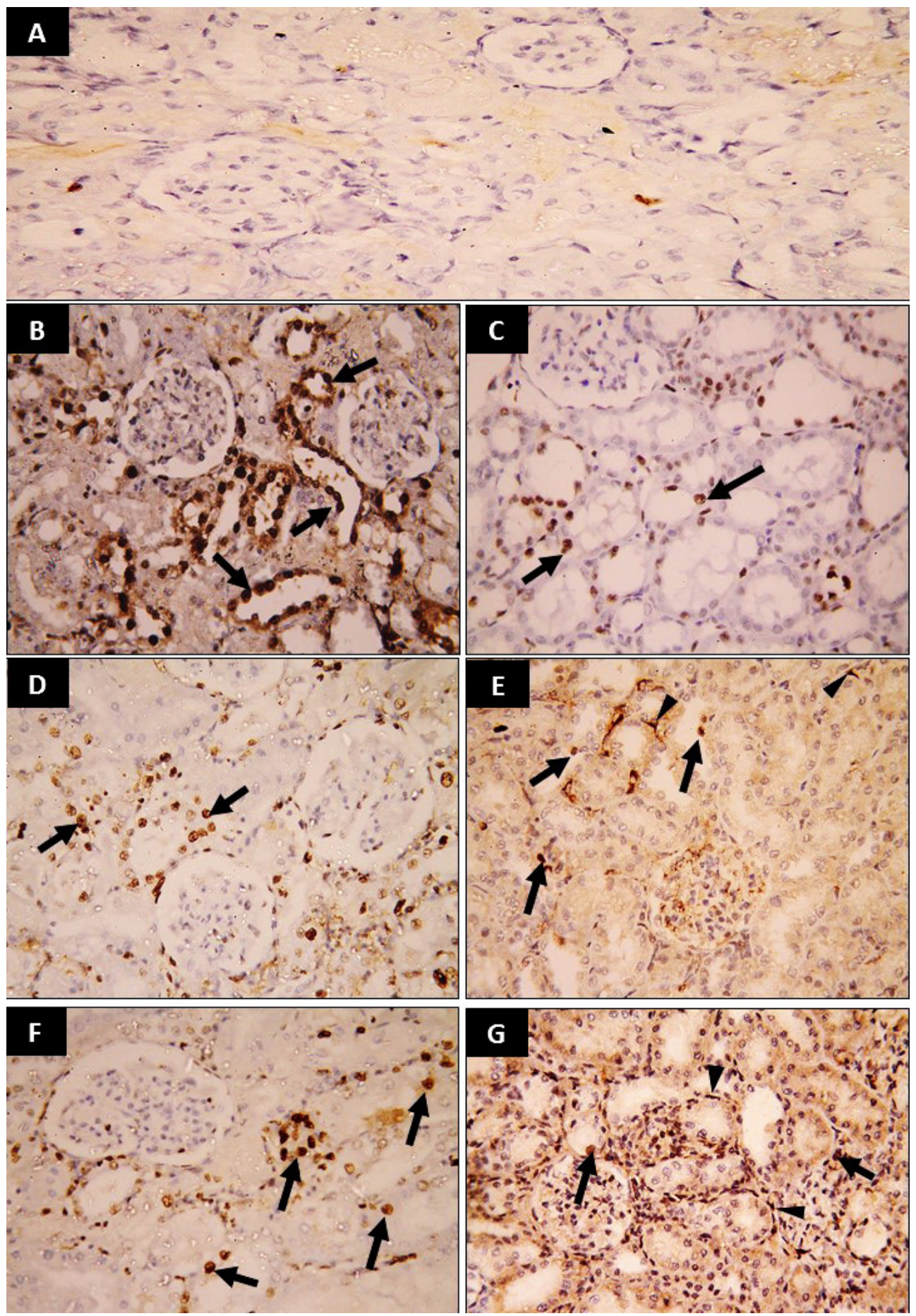

Fig. 12: Photomicrographs showing immunohistochemical reaction to PCNA in different subgroups. (A): Control group: PCNA positive cells are hardly detected; (B): GM toxicity (subgroup IIa): marked PCNA positive reaction in the tubular epithelium. The entire lining of some tubules shows positive nuclear reaction to the stain ( $\uparrow)$; (C): GM recovery (subgroup IIb): PCNA positive reaction was detected in some epithelial cells lining the tubules ( $\uparrow$ ). (D): BMSCs protection (subgroup IIIa): apparent increase in the number of tubular cells showing positive immune-reaction to PCNA ( $\uparrow$ ); (E): vitamin $\mathrm{C}$ protection (subgroup IIIb): Few cells lining the tubules are showing positive immune reaction ( $\uparrow$ ), however, the immune reaction could also be detected in interstitial cells surrounding cortical structures $(\boldsymbol{\Delta})$; (F): BMSCs treatment (subgroup IVa) Some epithelial cells of the renal tubules show positive PCNA reaction ( $\uparrow$ ); and (G): vitamin $\mathrm{C}$ treatment (subgroup IVb): interstitial cells are showing positive immune reaction to PCNA, however, very minimal tubular cells express positive PCNA immune reaction. (Immunohistochemical stain X400) 


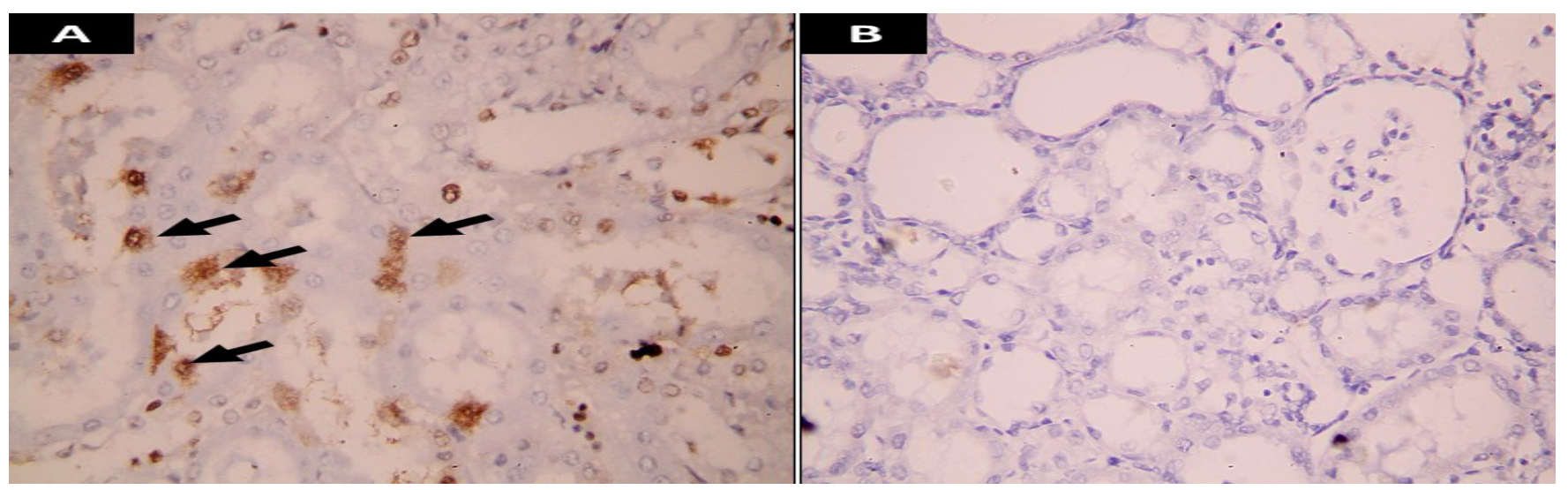

Fig. 13: A photomicrograph showing immune reaction to CD44. (A): BMSCs treatment (subgroup IVa): positive cytoplasmic immune reaction in the tubular epithelial cells $(\uparrow)$. (B): BMSCs protection (subgroup IIIb): no positive immune reaction to CD44 is detected. (Immune-histochemical stain X400)

Table 1: Semiquantitative analysis of renal cortex histology (number of sections examined).

\begin{tabular}{lcccccc}
\hline \multirow{2}{*}{\multicolumn{1}{c}{ Groups }} & \multicolumn{5}{c}{ Grade } \\
\cline { 2 - 6 } & 0 & $1+$ & $2+$ & $3+$ & $4+$ \\
\hline Group I (Control) & 13 & 2 & -- & -- & -- \\
Subgroup IIa (GM toxicity) & -- & -- & -- & 1 & 14 \\
Subgroup IIb (GM recovery) & -- & -- & 1 & 4 & 10 \\
Subgroup IIIa (BMSCs protection) & -- & -- & 1 & 5 & 9 \\
Subgroup IIIb (vitamin C protection) & 10 & 5 & -- & -- & -- \\
Subgroup IVa (BMSCs treatment) & 1 & 12 & 2 & -- & -- \\
Subgroup IVb (vitamin C treatment) & 12 & 3 & -- & -- & -- \\
\hline
\end{tabular}

$0=$ normal; 1 = desquamation of tubular epithelial cells in small foci (less than $1 \%$ of total tubule population involved); 2 = tubular epithelial necrosis and desquamation easily seen but involving less than half of cortical tubules; 3 = more than half of cortical tubules show desquamation and necrosis but uninvolved tubules easily found; $4=$ complete or almost complete proximal tubular necrosis.

Table 2: Mean \pm SD of PCNA positive tubular cells/HPF and area percentage of collagen fibers in renal cortex

\begin{tabular}{lcc}
\hline \multicolumn{1}{c}{ Groups } & $\begin{array}{c}\text { PCNA positive } \\
\text { tubular cells } \\
\text { (cells/HPF) }\end{array}$ & $\begin{array}{c}\text { Area \% of } \\
\text { collagen fibers } \\
\text { in renal cortex }\end{array}$ \\
\hline Group I (Control) & $2.1 \pm 1.3^{*}$ & $3.07 \pm 0.32^{*}$ \\
Subgroup IIa (GM toxicity) & $83.2 \pm 2.9^{*}$ & $11.81 \pm 0.31^{\star}$ \\
Subgroup IIb (GM recovery) & $56.5 \pm 3.41^{\bullet}$ & $12.1 \pm 0.23^{\star \Delta}$ \\
Subgroup IIIa (BMSCs protection) & $53.0 \pm 3.5^{*}$ & $11.71 \pm 0.35^{* *}$ \\
Subgroup IIIb (vitamin C protection) & $12.7 \pm 1.7^{*}$ & $10.17 \pm 0.35^{*}$ \\
Subgroup IVa (BMSCs treatment) & $40.5 \pm 2.08^{*}$ & $11.88 \pm 0.41^{\star}$ \\
Subgroup IVb (vitamin C treatment) & $10.1 \pm 0.9^{*}$ & $12.02 \pm 0.30^{*}$ \\
\hline
\end{tabular}

(*) Significant difference with all groups; $(\bullet)$ Significant difference with control, subgroups IIa, IIIb, IVa and IVb; (*) Significant change with control, IIa, IIb, IIIa and IVa $(\diamond)$ Significant difference with the control and subgroup IIIb; $(\Delta)$ Significant difference with subgroup IIIa; $(*)$ Significant difference with subgroup IIb.
Table 3: Levels of serum creatinine and blood urea nitrogen in different groups

\begin{tabular}{lcc}
\hline \multicolumn{1}{c}{ Groups } & $\begin{array}{c}\text { Serum } \\
\text { Creatinine } \\
(\mathrm{mg} / \mathrm{dl})\end{array}$ & $\begin{array}{c}\text { BUN } \\
(\mathrm{mg} / \mathrm{dl})\end{array}$ \\
\hline Group I (Control) & $0.53 \pm 0.02^{\Delta^{\bullet}}$ & $18.9 \pm 0.86^{\Delta}$ \\
Subgroup IIa (GM toxicity) & $1.98 \pm 0.06^{\star}$ & $25.3 \pm 0.92^{\star}$ \\
Subgroup IIb (GM recovery) & $1.59 \pm 0.04^{*}$ & $22.1 \pm 1.08^{*}$ \\
Subgroup IIIa (BMSCs protection) & $1.52 \pm 0.08^{*}$ & $21.9 \pm 1.16^{*}$ \\
Subgroup IIIb (vitamin C protection) & $0.59 \pm 0.04^{\Delta^{*}}$ & $19.6 \pm 0.88^{\Delta}$ \\
Subgroup IVa (BMSCs treatment) & $0.71 \pm 0.09^{\star}$ & $19.9 \pm 1.2^{\Delta}$ \\
Subgroup IVb (vitamin C treatment) & $0.55 \pm 0.05^{\Delta^{*}}$ & $19.02 \pm 0.89^{\Delta}$ \\
\hline
\end{tabular}

$(\Delta)$ Significant difference with subgroups IIa, IIb, and IIIa; $(\bullet)$ Significant difference with subgroup IVa; $(\diamond)$ Significant difference with all groups; (*) Significant difference with control group, subgroups IIa, IIIb, IVa, $\mathrm{IVb}$.
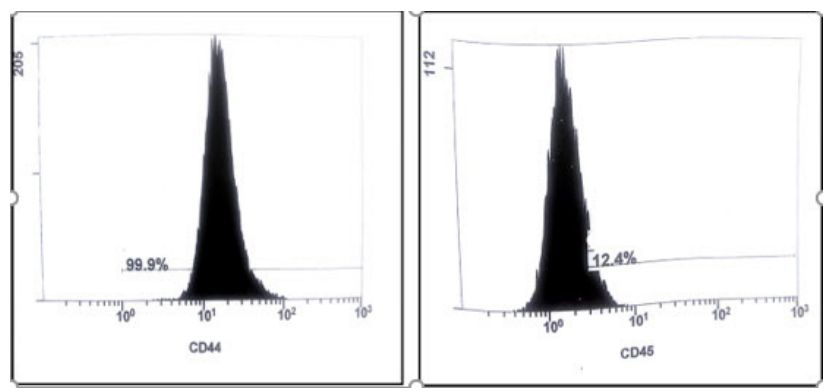

Histogram 1: Flow cytometric analysis of third passaged BMSCs reveals $99.9 \%$ of cells are positive for CD44, but they don't express the hematopoietic marker CD45 $(<12.4 \%)$.

\section{DISCUSSION}

Gentamicin is probably the most commonly used of all the aminoglycosides antibiotics despite its possible severe side effects as nephrotoxicity. This is due to its advantage over other antibiotics in some clinical situations ${ }^{[3]}$. 
Gentamicin nephrotoxicity has been investigated in several experimental models, in an attempt to protect or reverse renal damage but these studies did not provide a detailed histological analysis for their results ${ }^{[19]}$.

The rational beyond focusing on the histological examination of the renal cortex but not the medulla in the results of the current study was based on the verified information that GM accumulates in epithelial cells of the proximal tubule $(\mathrm{PCT})^{[3,20]}$.

Gentamicin enters PCT via endocytosis mediated by the megalin receptor located deeply at the base of the brush border. Then, the drug receptor complex internalized via pinocytosis, that ends with fusion of endocytotic vacuoles with lysosomes. The drug mostly accumulates in the lysosomes inducing membrane destabilization, lysosomal aggregation, alteration of lipid metabolism, and phospholipidosis, which have been associated with cell death $^{[3]}$.

In the present study, administration of $100 \mathrm{mg} / \mathrm{kg} \mathrm{GM}$ for 8 days in GM toxicity subgroup resulted in severe distortion in the cortical structure of the kidney. The tubular epithelium showed vacuolation, desquamation of epithelial lining of the tubules and appearance of homogenous acidophilic casts in tubular lumina. The nuclei of some cells showed pyknosis, foci of inflammatory cells and congested dilated vessels.

Similar results were reported by previous studies ${ }^{[3,5-7]}$. However, Racusen, $1995^{[20]}$ explained that desquamation of cells was due to alterations in cell microfilaments and/ or surface attachment proteins which alter cell adhesion. $\mathrm{He}$ added that rearrangement of integrin molecules on cell membranes contributed not only to decrease adhesion but also to sloughing of cells, leading to tubular obstruction.

Moreover, nuclear pyknosis in PCT and subsequent tubular necrosis mostly occurred due to activation of poly (ADP-ribose) synthetase (PARP). PARP is a nuclear enzyme that depletes cellular nicotinamide adenine dinucleotide (NAD) and adenosine triphosphate (ATP) levels, thus drives the cell to necrosis ${ }^{[21]}$.

The appearance of inflammatory cells in the renal interstitium was attributed to stimulation of inflammatory events due to renal injury. These events included recruiting intercellular adhesion molecules (ICAM) and monocyte chemoattractant protein at the site of injury that enhance the migration of monocytes and macrophages at the site of tissue damage ${ }^{[22]}$.

In the current study, allowing the kidney to recover for 8 days after an equal interval of GM administration in subgroup IIb resulted in persistence of cortical distortion. PCT appeared with obliterated lumina, gaps between PCT along the tubular basement membrane in some tubules, blebbing of the apical cytoplasm, pyknotic nuclei of PCT. On the other hand, minimal signs of cortical recovery in the form of PCT having vesicular nuclei were observed.
It was reported that blebs from the cell surface were described to be lacking cytoskeletal elements and were due to decreased strength of membrane integral proteincytoskeletal interactions ${ }^{[20]}$.

The gaps between PCT were attributed to exfoliation of some tubular cells along the tubular basement membrane which appeared either denuded of cells or covered by only a thin layer of cell cytoplasm ${ }^{[20]}$.

The persistence of cortical distortion in GM recovery subgroup in our results was contradictory to a number of well-documented researches ${ }^{[23-25]}$ that proved the ability of PCT to regenerate following tubular necrosis. However, the exact mechanism for this regeneration is a matter of debate ${ }^{[26]}$.

This contradiction might be explained on the basis that, GM accumulated in the kidney retained intracellularly or bound to a tissue component. As tissue half-life of the drug was far longer than serum half-life ${ }^{[27]}$, this might result in prolonging the action of the drug at the cellular level after stopping the drug, preventing the regeneration process.

These histological results were reflected on kidney functions as indicated by biochemical analysis for the serum level of Creatinine and Urea. In both GM subgroups (toxicity and recovery), serum creatinine and BUN showed significant increase especially in GM toxicity subgroup.

In the present study, simultaneous injection of BMSCs with GM in subgroup IIIa, did not provide protection against GM toxicity. The cortical tissue showed histological picture similar to the toxicity subgroup. On the contrary, BMSCs injection after stopping GM injection in subgroup IVa resulted in regeneration of the cortical tissue. The tubules were dilated and lined with low cuboidal cells having vesicular nuclei.

These histological results were further confirmed with the biochemical analysis of serum creatinine and BUN in which a non-significant change was detected between GM toxicity (subgroup IIa) and GM recovery (subgroup IIb) subgroups on one hand and BMSCs protection subgroup (subgroup IIIa) on the other hand. In contrast, stem cell treatment resulted in a significant decrease in serum creatinine and BUN in comparison to GM toxicity and GM recovery subgroups.

Mesenchymal stem cells are well recognized as selfrenewable, multipotent progenitor cells with the capacity to differentiate into several distinct mesenchymal lineages ${ }^{[9]}$. However, the mechanism by which MSCs functionally contribute to tissue repair is a matter of debate.

Some studies reported that the injected BMSCs were capable of infiltrating the damaged tissue, and directly populate the injured $\operatorname{sites}^{[9]}$. While, other studies have found only transient evidence of injected BMSCs in the vasculature of injured organs and no evidence for direct MSCs incorporation into injured sites during the repair processes, suggesting paracrine effects ${ }^{[1]}$. 
Our results concerning BMSCs injection for protection, were in accordance to the results previously reported by Reis et al., 2012 ${ }^{[1]}$. They suggested that MSCs were unable to prevent the damaging effect of GM because BMSCs were rapidly removed when simultaneously injected with $\mathrm{GM}$, as no lesions were present yet in renal tissue to allow for the homing of stem cells.

Conversely, following tissue injury, BMSCs underwent selective recruitment to injury sites in response to complex signaling pathways involving cytokines. The homing process includes, vascular rolling and adhesion, endothelial transmigration and, finally, movement within the extracellular space to the injury site ${ }^{[28]}$.

This information explains our results regarding the absence of CD44 positive cells -a well-known marker for rat MSCs- in the renal cortex in the prevention subgroup (Subgroup IIIa), and their detection in BMSCs treatment subgroup (subgroup IVa). However, the minimal detection of CD44 positive stem cells in subgroup IVa (MSCs treatment), suggested that MSCs exerted its repairing effect mainly through a paracrine action.

In this view, Reis et al., 2012 $2^{[1]}$ proved that, the effects of the BMSCs on the recovery of renal function in GM induced acute renal injury model, were mediated by microand mRNA and other factors present in the microvesicles released by MSCs. These results provide a rationale for the administration of the conditioned medium from MSCs and avoidance of cell transplantation in the treatment of nephrotoxicity.

In the current study, simultaneous injection of Vitamin C with GM for 8 days (subgroup IIIb), protected the renal cortex from GM toxicity. This protective effect was reflected on the histological structure of the renal cortex. Most tubules were crowded with proliferating epithelial cells and were having star shape lumina comparable to the control group. Only few tubules were showing minimal features of degeneration.

Moreover, vitamin $\mathrm{C}$ injection after 8 days of GM daily doses for an equal interval in vitamin $\mathrm{C}$ treatment (subgroup IVb), resulted in a picture comparable to the control group, reflecting their competent ameliorative effect on the structure of the kidney following GM toxicity.

These histological findings were in correlation with the results of the biochemical analysis of serum creatinine and BUN, in which no significant difference was calculated between both vitamin $\mathrm{C}$ subgroups (protection and treatment) and the control group. This reflected the ability of vitamin $\mathrm{C}$ to restore the physiological function of the kidney.

One of the known mechanisms of GM toxicity is the generation of hydroxyl radical, a reactive oxygen species (ROS) in mitochondria of renal cortical cells leading to their damage. Therefore, spill ROS out into the cytoplasm which further aggravate damage to the various subcellular structures. Also, cause suppression of cellular DNA synthesis resulting in loss of cell integrity and protein leakage ${ }^{[5]}$.

Considering the previous established mechanism of GM toxicity, we tried to explore the protective and therapeutic effect of Vitamin C on the kidney structure in GM toxicity. Vitamin $\mathrm{C}$ is potent natural antioxidant capable of reducing oxidative stress, scavenging free radicals and reestablishing antioxidative systems, that was reported to protect the kidney against gentamicin-associated oxidative stress and preserve normal renal functions in several studies ${ }^{[3,6,28]}$.

This explains our findings in the subgroup IIIb (vitamin C protection), in which the concomitant injection of Vitamin $\mathrm{C}$ with GM, effectively prevented the production of ROS, hence preventing its damaging effect on renal cortex. Also, in subgroup IVb (vitamin C treatment), injection of vitamin $\mathrm{C}$ one day after the last dose of GM, sufficiently reduced the toxic effect of GM, allowing regeneration of the tubular cells.

The previous histological results were confirmed by semiquantitative analysis and histological grading according to Houghton et $a l^{[18]}$. Results showed that renal cortex was markedly affected in GM toxicity, GM recovery and BMSCs protection respective to the grading value. On the other hand, vitamin $C$ treatment, vitamin $C$ protection and stem cell treatment resulted in much better amelioration of cortical histology.

In the current study, staining kidney sections by Masson's trichrome stain for demonstration of collagen revealed collagen deposition in the interstitium around cortical structures. The statistical analysis of the area percentage of collagen in different group was calculated to confirm the statistical significance.

The injured tubule cells initiate a local inflammation, which will finally lead to the removal of all tubular remnants and the formation of a local area of fibrosis, finally a scar. The local inflammatory process surrounding a degenerating tubule consists of the massive accumulation of myofibroblasts that organize the interstitial fibrosis by synthesizing type I collagen and finally by contraction of the affected area to a scar ${ }^{[31]}$.

The sources for these myofibroblasts are controversial They might develop from resident interstitial cells, which are generally called interstitial fibroblasts, or from injured tubular cells by a process called "epithelial to mesenchymal transition". Also, a contribution of bone-marrow derived "fibrocytes" is generally considered ${ }^{[29]}$.

This information about the initiation of inflammation by the injured tubules, might explain our results in which no significant difference was estimated between GM toxicity, GM recovery, BMSCs protection, stem cell treatment and vitamin c treatment subgroups. In all these subgroups the kidney was subjected to the injurious effect of GM, and attempted to heal either passively (GM toxicity, GM recovery and BMSCs protection) or with the aid of 
other factors (stem cell treatment and vitamin C treatment subgroups).

However, there is no certain knowledge whether kidney fibrosis during injury is protective, injurious or restorative. Kaissling et al. $2013^{[29]}$ considered fibrosis as a healing process, which results in the formation of a scar in the place of a lost nephron or supports the healing of a nephron.

This concept contrasts with the prevalent view that renal fibrosis contributes to the deterioration of the kidney ${ }^{[30]}$. Yet, it could explain the increase in the percentage of collagen in vitamin $\mathrm{C}$ protection, vitamin $\mathrm{C}$ treatment and stem cell treatment subgroups, in which we observed marked improvement of the kidney on the microscopic and physiological level.

Moreover, in vitamin $\mathrm{C}$ subgroups (protection and treatment), in which a significant change in the area percentage of collagen was estimated, could be attributed to the well-established effect of vitamin $\mathrm{C}$ on collagen synthesis.

Vitamin $\mathrm{C}$ is essential for collagen formation as it is a required component in the synthesis of hydroxyproline and hydroxylysine in collagen. Hydroxyproline serves to stabilize the collagen triple helix and hydroxylysine is necessary for formation of the intermolecular crosslinks in collagen $^{[31]}$.

Hence, in vitamin $\mathrm{C}$ protection subgroup, collagen percentage was significantly increased in comparison to the control due to its direct effect on collagen synthesis. While, in vitamin $C$ treatment subgroup, we deduced that collagen deposition was remarkably increased with respect to other subgroups, not only due to stimulation of myofibroblast by injurious effect of GM, but also, due to the direct effect of vitamin $\mathrm{C}$ on collagen synthesis.

In the present study, there was a significant increase in the number of PCNA positive tubular cells in GM toxicity, GM recovery as well as in BMSCs protection subgroups. On the other hand, this number was decreased in BMSCs treatment subgroup and both vitamin $\mathrm{C}$ injected subgroups.

Normally, differentiated tubular cells show slow rate of proliferation. However, the proximal tubule contains a large fraction of cells arrested in G1 that constitutes a "ready-togo" pool of cells to immediately start proliferation in case of a tubular injury.

On the other hand, there is a fraction of cells that does not properly participate in the process of regeneration. These cells are arrested in G2/M produce profibrotic factors including connective tissue growth factor and transforming growth factor beta. They are likely the cause of the failure of some tubules to regenerate, consequently the triggers of the peritubular inflammation ${ }^{[32]}$.
In our results, although proliferating cells were increased in GM toxicity, GM recovery and BMSCs subgroups, they failed to restore the damaged tubular cells as revealed by $\mathrm{H} \& \mathrm{E}$ results and histological grading. This failure might be attributed to the toxic effect of the drug that was beyond the regenerative capacity of the proliferating cells.

On the contrary, the sufficient protection of vitamin C against the toxic effect of the GM in subgroup IIIb, was denoted by the significant decrease in PCNA positive tubular cells. As explained, the number of proliferating cells is directly proportional to the degree of insult to the kidney.

Moreover, in vitamin $\mathrm{C}$ treatment (subgroup $\mathrm{IVb}$ ), although PCNA positive tubular cells were markedly decreased, a considerable number of PCNA positive cells were detected in the intersitium surrounding the tubules.

This finding might be explained in the view that, in acute tubular injury, tubules undergo expansion caused by elevated intratubular pressures. Myofibroblasts that arise in the intersitium, gather around such tubules in a circular arrangement tightly fixing to the tubular basement membrane. These contractile cells might counteract further expansion of the tubule and thereby favor tubular recovery ${ }^{[33]}$.

Therefore, we suggested that these PCNA positive interstitial cells are myofibroblasts that were activated to protect the tubules in a double action mechanism. First, through aggregation around the injured tubules in circular arrangements to prevent further tubular expansion. Second, through stimulation to synthesize collagen fibers which localize the injurious effects and support the remaining nephrons through scar formation. Fortunately, according to our results, these two mechanisms were stimulated by vitamin $\mathrm{C}$ injection.

\section{CONCLUSION}

The current study provided an evidence that, concomitant injection of BMSCs with GM, failed to protect the kidney against GM toxicity, whereas, post injection of BMSCs after kidney injury by GM, assisted kidney regeneration to some extent.

On the other hand, vitamin $\mathrm{C}$ administration, whether concomitantly or post injected with GM, showed a significant improvement in kidney structure and biochemical results.

\section{RECOMMENDATIONS}

Based on the results of the current study, it is strongly recommended to use vitamin $\mathrm{C}$ during and after the administration of GM. However, further investigations are needed to adjust the exact dose and route of administration of vitamin $\mathrm{C}$.

\section{CONFLICT OF INTEREST}

There are no conflicts of interest. 


\section{REFERENCES}

1. Reis LA, Borges FT, Simo es MJ, Borges AA, Sinigaglia-Coimbra $\mathrm{R}$, et al. Bone marrow-derived mesenchymal stem cells repaired but did not Prevent gentamicin-induced acute kidney injury through paracrine effects in rats. PLoS ONE,2012; 7(9): e44092.

2. Vakulenko S and Mobashery S. Versatility of aminoglycosides and prospects for their future. Clin Microbiol Rev, 2003; 16(3): 430-450.

3. Balakumar P, Rohilla A and Thangathirupathi A. Gentamicin-induced nephrotoxicity: Do we have a promising therapeutic approach to blunt it? Pharmacol Res, 2010; 62: 179-186.

4. Tavafi M. Protection of renal tubules against gentamicin induced nephrotoxicity. J Renal Inj Prev, 2013; 2(1): 5-6.

5. Acharya C, Thakar H and Vajpeyee S. A study of oxidative stress in gentamicin induced nephrotoxicity and effect of antioxidant vitamin $\mathrm{C}$ in Wistar rats. Nat J Physio Pharma Pharmacol, 2013; 3 (1): 14 - 20.

6. Derakhshanfar A, Roshanzamir $M$ and Bidadkosh A. Dose-related protecting effects of vitamin $\mathrm{C}$ in gentamicin-induced rat nephrotoxicity: a histopathologic and biochemical study. Comp Clin Pathol, 2013; 22(3): 441-447.

7. Aldallal A. Vitamin C, an antioxidant attenuates gentamicin-induced acute Kidney injury in female albino Wister rats. Med J Babylon, 2013; 10(3): 656-661.

8. Herrera MB, Bussolati B, Bruno S, Fonsato V, Romanazzi GM, et al. Mesenchymal stem cells contribute to the renal repair of acute tubular epithelial injury. Int J Mol Med,2004; 14:1035-1041.

9. Morigi M, Imberti B, Zoja C, Corna D, Tomasoni S, et al. Mesenchymal stem cells are renotropic, helping to repair the kidney and improve function in acute renal failure. J Am Soc Nephrol, 2004; 15:1794-1804.

10. Zhu XY, Urbieta Caceres V, Krier JD, Textor SC, Lerman A and Lerman LO. Mesenchymal stem cells and endothelial progenitor cells decrease renal injury in experimental swine renal artery stenosis through different mechanisms. Stem Cells, 2013; 31: 117125.

11. Bian X, Zhang B, Guo W, et al. Effects of mesenchymal stem cells transplanted at different time points in a rat remnant kidney model. Am J Nephrol, 2014; 39: 7584 .

12. Bussolati B, Tetta $\mathrm{C}$ and Camussi G: Contribution of stem cells to kidney repair. Am J Nephrol,2008; 28: 813822

13. Lin F, Moran A and Igarashi P. Intrarenal cells, not bone marrow-derived cells, are the major source for regeneration in post-ischemic kidney. J Clin Invest,2005;115:1756-1764.

14. Lennon DP and Caplan AI. Isolation of rat marrowderived mesenchymal stem cells. Exp Hematol, 2006; 34(11):1606-1607.

15. Ra JC, Shin IS, Kim SH, Kang SK, Kang BC, et al. Safety of intravenous infusion of human adipose tissue-derived mesenchymal stem cells in animals and humans. Stem Cells and Development, 2011; 20: $1297-1308$

16. Hur E, Garip A, Camyar A, Ilgun S, Ozisik M, Tuna S, Olukman M, et al. The effects of vitamin $\mathrm{D}$ on gentamicin-induced acute kidney injury in experimental rat model. Int $\mathbf{J}$ Endocrinol, 2013; 313528 .

17. Bancroft GD and Gamble M. Theory and practice of histological techniques. 6th ed (2008). Philadelphia: Churchill Livingstone, Elsevier.

18. Houghton DC, Plamp CE, DeFehr JM, Bennett WM, et al. Gentamicin and tobramycin nephrotoxicity. A morphologic and functional comparison in the rat. Am. J. Pathol, 1978; 93:137-152.

19. Ali BH, Al Za'abi M, Blunden $\mathrm{G}$ and Nemmar A Experimental gentamicin nephrotoxicity and agents that modify it: a mini-review of recent research. Bas Clini Pharmacol Toxicol, 2011; 109, 225-232.

20. Racusen LC. The histopathology of acute renal failure. New Horiz, 1995; 3(4):662-668.

21. Cuzzocrea S, Mazzon E, Dugo L, Serraino I, Di Paola $\mathrm{R}$, Britti $\mathrm{D}$, et al. A role for superoxide in gentamicinmediated nephropathy in rats. Eur J Pharmacol 2002; 450:67-76.

22. Geleilete TJ, Melo GC, Costa RS, Volpini RA, Soares TJ and Coimbra TM. Role of myofibroblasts, macrophages, transforming growth factor-beta endothelin, angiotensin-II, and fibronectin in the progression of tubulointerstitial nephritis induced by gentamicin. J Nephrol, 2002; 15:633-42.

23. MC Campbell KK and Wingert RA. Renal stem cells: fact or science fiction? Biochem J, 2012; 444: 153-168.

24. Little MH. Regrow or Repair: Potential Regenerative Therapies for the Kidney. J Am Soc Nephrol, 2006; 17: 2390-2401.

25. Humphreys BD, Valerius MV, Kobayashi A, Mugford J W et al., Intrinsic Epithelial Cells Repair the Kidney after Injury. Cell Stem Cell, 2008; 2, 284-291.

26. Berger K, Dipl-Biol and Moeller MJ. Mechanisms of Epithelial Repair and Regeneration After Acute Kidney Injury. Semin Nephrol, 2014;34:394-403.

27. Luft FC and Kleit SA.Renal parenchymal accumulation of aminoglycoside antibiotics in rats. J Infect Dis, $1974 ; 130,656-659$. 
28. Rennert RC, Sorkin M, Garg RK, and Gurtner GC. Stem cell recruitment after injury: lessons for regenerative medicine. Regen Med, 2012; 7(6): 833-850.

29. Kaissling B, LeHir M and Kriz W. Renal epithelial injury and fibrosis. Biochimica et Biophysica Acta, 2013; 1832: 931-939.

30. Y. Liu, Renal fibrosis: new insights into the pathogenesis and therapeutics. Kidney Int, 2012; 69: 213-217.

31. DePhillipo NN, Aman ZS, Kennedy MI, Begley JP et al. Efficacy of vitamin $\mathrm{C}$ supplementation on collagen synthesis and oxidative stress after musculoskeletal injuries. A systematic review. Ortho J Sport Med, 2018; 6(10): 1-9.

32. Qi R and Yang C. Renal tubular epithelial cells: the neglected mediator of tubulointerstitial fibrosis after injury. Cell Death and Disease, 2018; 9:1126.

33. Fujigaki $\mathrm{Y}$, Muranaka $\mathrm{Y}$, Sun $\mathrm{D}$, Goto $\mathrm{T}$ et al. Transient myofibroblast differentiation of interstitial fibroblastic cells relevant to tubular dilatation in uranyl acetateinduced acute renal failure in rats. Virchows Arch,2005; 446: 164-176. 


\section{الملخص العربى}

\section{التثأثير العلاجي والوقائي المحتمل لاخلايـا الجذعية الوسيطة مقارنة بفيتامين سي في

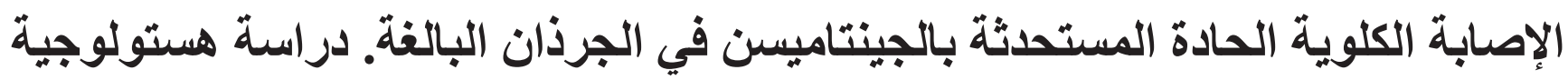 \\ ولاء باهر، أسماء عبد المنعم أبوزيل، هدوى علي عبد الخالق

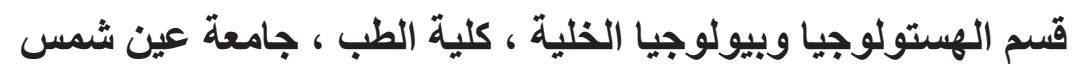

الهدف:صممت هذه الدر اسة لتقييم الدور الوقائي و العلاجي لخلايا نخاع العظم الوسطية بالمقارنة بفيتامين سي في نموذج التسمم الكلوي المستحدث بالجينتاميسين في الجرذان. المواد و الطرق: تم استخدام أربعون من ذكور الجرذان البالغة (10 ـ ـ . . . جم). تم استخدام خمسة جرذان لفصل الخلايا الجذعية من نخاع العظم، وتققيم خمسة وثلاثين اخرين إلى أربع مجموعات : مجموعة ا (الضابطة)، المجموعة ץ ( مجموعة الجينتاميسن): حيث تلقت . . (مجم/كجم من الجينتاميسين عن طريق الحقن العضلي لمدة ثمانية أبام. وقسمت الى المجموعة الفر عية ب أ (التسمم بالجينتاميسن) :تمت التضحية بالحيو انات بعد اخر جر عة حقن من الجينتاميسن، والمجموعة الفرعية ب ب( التعافي من الجينتاميسين): تمت التضحية بالحيو انات بعد مرور ثمانية

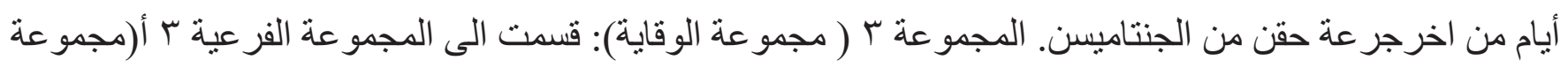
الوقاية بخلايا نخاع العظم الوسيطة) حيث تلقت الحيو انات حقنة واحدة من خلايا نخاع العظم الوسيطة عن طريق الوريد وذللك مع أول جر عة من الجينتاميسن ،و المجموعة الفرعية ب ب(مجمو عة الوقاية بفيتامين سي):حيث تلقت . . rمجم/ كجم من فيتامين سي عن طريق الحقن البريتوني لمدة ثمانية ايام وذللك بالتز امن مع الجرعات اليومية من الجينتاميسن. المجمو عة ؛ (مجموعة العلاج) وقسمت الى المجموعة الفرعية ؛ أ(مجموعة الوقاية بخلايا نخاع العظم الوسيطة) حيث تلقت الحيو انات خلايا نخاع العظم الوسيطة عن طريق الوريد بعد اخر جرعة من الجينتاميسن، بينما تلقت حيوانات المجمو عة الفرعية ؟ ب (مجموعة العلاج بفيتامين سي) حيث تلقت . . ب مجم/كجم من فيتامين سي عن طريق الحقن البريتوني لمدة ثمانية أيام بعد اخر جر عة من الجينتاميسن. تم قياس مستوى الكرياتينين و اليوريا في مصل الدم وفي نهاية التجربة تم اعداد الكلى للار اسات الهيستولوجيه و الهيستوكيميائيه المناعيه و الدر اسات القياسية. النتائج: لقد ادى الجينتاميسن الى احداث تقتشر وتشكل فجوات في الطبقة الطلائية للانابيب وكذللك التهاب خلالي و احتقان دموي. و أدى الى زيادة عدد الخلايا الموجبة للـ PCNA ـ كما ادى ايضا الى زيادة ملحوظة في مستوى الكرياتينين و اليوريا في مصل الدم ـ ان اعطاء فيتامين سي كوقاية او كعلاج ادى الى تحسن هذه التغيرات. وفي المقابل فان خلايا

نخاع العظم الوسيطة لم تتمكن من منع التسمم بالجينتاميسن ولكنها احدثت دور ا علاجيا. الاستنتاج: خلايا نخاع العظم الوسيطة ليس لها دور في الوقاية من التسمم الكلوي بالجينتاميسن بينما اعطاؤها بعد الاصابة الكلوية قد ادى الى المساعدة في التجدد الكلوي. اما فيتامين سي فقد اظهر دورا مزدوجا مؤثرا في حماية واصلاح تركيب الكلى وكذللك النتائج البيوكيميائية. 